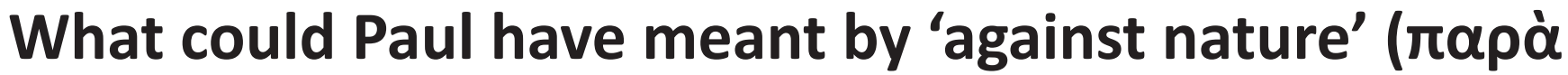

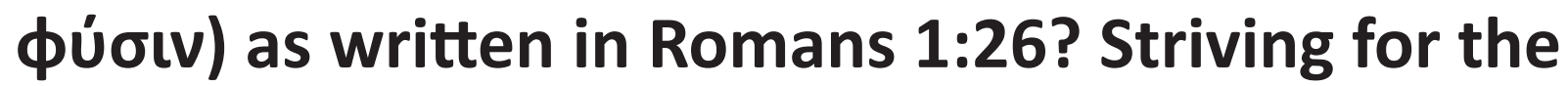 well-being and health of all people
}

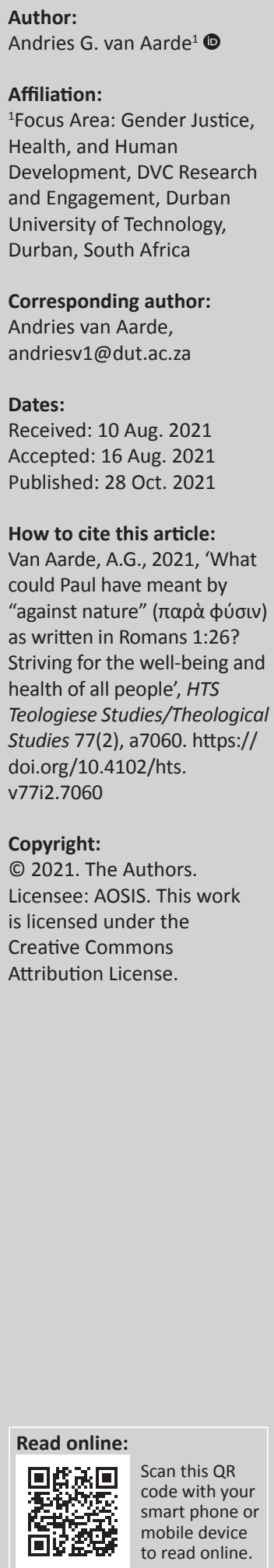

The point of departure of this article is postmodern philosopher Michel Foucault's 'archaeological analysis' of the history of sexuality, seen from the lens of the South African philosopher Johann Beukes. Foucault points out that since the circulation of the so-called handbooks on penance in the 6th century CE, same-gender sex was seen as a punishable sin. With regard to perspectives before this period, Foucault reflects specifically on the contribution of the Christian theologian Augustine (354-430 CE), and particularly Augustine's interpretation

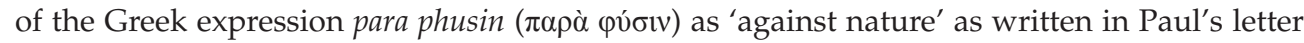
to the Romans (1:26). He argues that this interpretation by Augustine represents a trend in contemporaneous thinking of non-Christian writers such as Plutarch and Themistios. The aim of this article is to demonstrate that a much more influential stimulus from another nonChristian thinker, namely Artemidorus of Daldis (2nd century CE), created a common context that influenced Augustine's views and subsequently those on same-gender sex, sexual identity, and heterosexual marriage within the Christian tradition.

Contribution: The article shows how modern-day homophobia and aversion in same-gender sex do not have its primarily ground in Paul's use of para phusin, but that Augustine and present-day homophobes in the Christian (including the Reformed) tradition do have their roots in a non-Christian conviction without realising its intercultural and non-Christian origins.

Keywords: gender justice; same-gender sex; pluriform sexual identities; heterosexual marriage; procreation; onanism; Artemidorus of Daldis; Augustine of Hippo.

\section{Sketching the décor}

The Christians who condemn homosexuality on biblical grounds will probably find their strongest biblical argument in Paul's letter to the Romans 1:18-32, especially the reference to same-gender sex as 'against nature':

For this cause God gave them up unto vile affections: for even their women did change the natural use into that which is against nature [in Greek: $\pi \alpha \rho \alpha \grave{~} \varphi v ́ \sigma v v]$. And likewise also the men, leaving the natural use of the woman, burned in their lust one toward another; men with men working that which is unseemly, and receiving in themselves that recompense of their error which was meet. (Kings James Bible 1611; Rm $1: 26-27)$

The New Living Translation (Holy Bible 2015) of the Tyndale House Foundation (see Holy Bible 2015) translates the expression 'against nature' with 'against the natural way to have sex'. This is one of the many ways in which the Bible ${ }^{1}$ provides the fundamental argument for homophobes to condemn 'homosexuality', as if same-gender sex is a divine sanctioned disgrace (cf. inter al Geyser 2002). However, some exegetes have tried to argue that Paul's remarks in Romans 1:26-27 should not be understood in an anachronistic way as references to 'homosexual' deeds. According to them (cf. Van Zyl 2016:2-8 of 13), they refer to either:

- idolatrous temple prostitution (Lenow 2006:33-34; Malick 1993:333), or

- the prejudice against impurity expressed in Israelite holy codes (Countryman 1988:117), or

- the transgression of divine creational intention expressed in the Old Testament writing Genesis (Cranfield 1975:125; Jewett 2007:177; Schreiner 1998:95), or

1.Leviticus $18: 22 ; 20: 13$, 1 Corinthians $6: 9-11$, 1 Timothy $1: 9-10$, Romans $1: 26-27$

Note: Special Collection: Gender Justice, Health and Human Development, sub-edited by Cheryl Potgieter (Durban University of Technology). 
- Graeco-Roman heterosexual hedonistic practices (Du Toit 2007:168-169), or

- heterosexual pederasty (Scroggs 1983:27-29; Smith 1996:227-232), or

- the vilification in general against gentile non-believers (Vorster 2006:451-452), or

- sexual extremities (Brownson 2013:161-163; Debel 2009:637; Hultgren 1994:319-320; Loader 2014:1-3; Steyn 2007:198-200; Ward 1997:284).

Whatever the counter hermeneutical argument - arguing for a culturally sensitive reading that tries to avoid

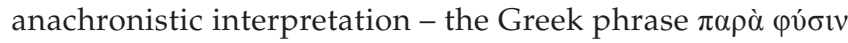
cannot but be understood as to mean 'against nature'. In the context of Romans 1:18-32, the phrase indeed semantically refers to 'against the natural way to have sex'. The question, however, is: why was the same-gender sex - considered to be 'anatomically' against the natural way to have sex - judged in biblical times as a divine sanctioned disgrace? Even more so, why would a 'disgrace' in antiquity remains to be an ignominy for Christians today or for present-day adherents of other Abrahamic monotheistic beliefs?

\section{Procreation is the issue}

It is being argued in this article that this expression, in contemporary Greek literature of the time, as well as later by both the church father Augustine who wrote in Latin and the Protestant Reformation in the 16th century, is exclusively about the phenomenon of the priority that reproduction had in antiquity in biblical times. The culture was hierarchical by nature, and the dominant role that men played in the issues of gender decidedly influenced the perspectives about sexuality. The important place that procreation played in society so strongly influenced the Christian church, that, on the one hand, the Roman Catholic Church is until this day, officially opposed against the use of contraceptives, because 'it is a sin against nature' (Schenker \& Rabenou 1993:15), and on the other, reproduction (proles) ${ }^{2}$ is described in the classical formulary of marriage in the Reformed tradition as one of the three intentions that God would have ordained (cf. Botha \& Dreyer 2007:1275-1298). The role that the biological family played in Reformed covenant theology - against Calvin's intention - has also indirectly influenced the same matter. Calvin did not see the covenant as being based on physical relationships, regulated by civil policy, but on the 'spiritual family', that represented the church. ${ }^{3}$ However, 'covenant theology' is embedded in bio-politics, a form of 'civil religion' in antiquity. Its context was that of the biological

2.See Dreyer (2008a:733): "Clearly the value of marriage cannot be located in proles (procreation) any longer. Such as value would be highly questionable in an overpopulated world where resources are dwindling to the extent that the existing population cannot be adequately supported'.

3.Calvin (1536) shared the Lutheran theory of the two kingdoms. Witte (1996) puts it as follows: 'Calvin used multiple terms to describe these two kingdoms: the heavenly kingdom, the Kingdom of Christ, the spiritual kingdom, the spiritual jurisdiction versus the earthly kingdom, the Kingdom of this world, the political jurisdiction versus the earthly kingdom, the Kingdom of this world, the political
kingdom, the civil realm, the temporal jurisdiction' (Witte 1996, note 24, viewed kingdom, the civil realm, the temporal jurisdiction' (Witte 1996, note
from https://papers.ssrn.com/sol3/papers.cfm?abstract_id=1669582). family and tribal insider group and the significance of procreation that also influenced the formative years of ecclesial institutionalisation. ${ }^{4}$

The overemphasis of procreation goes back to the use of the expression para fusin (unnatural) that is also found in Romans 1:26. Christians who interpret the expression para fusin in light of the emphasis on the divine order of procreation through the sexual relationship of man and woman ground their conviction on the biblical creation narratives. Genesis 1:28 $8^{5}$ serves as locus classicus - the biblical text considered to be the most authoritative - for the divine ordinance of procreation and marriage. The prominence of procreation during post-biblical times was specifically perpetuated by Saint Augustine of Hippo (born 13 November 354 CE; died 28 August $430 \mathrm{CE}$ ). Augustine was the theologian more than all others who bridged the period between antiquity and medieval times and the 16th century Protestant Reformation by connecting para fusin in Romans 1:26 with Genesis 1:28.

Origen of Alexandria (c. 184 - c. 253) as well as Hieronymus of Stridon (Jerome) (c. 342-347) followed both Plato ${ }^{6}$ and Aristotle $^{7}$ (see Beukes 2021a) and judged 'sexual pleasure' as an inferior physicality of the failing body in comparison to the higher values of the soul and therefore objectionable behavior. Augustine was of a similar opinion, especially in his post-conversion and post-Manicheanism period, especially his view on sin and concupiscence in his Confessions (see Van Oort 2020:93-106).

A few patristic scholars stigmatised the reference to samegender sex in Romans 1:26 as lewdness and therefore sinful, guilty to the so-called sin of onanism, for example, John Chrysostom, archbishop of Constantinople, who died 14 September $407 \mathrm{CE}$. In his 'Homilia IV', Epistola ad Romanos (see De Wet 2014:213-214), Chrysostom interprets

4 Civil religion was to relive again centuries later when a nation-state ideology would give rise to nationalism in the late 18th and in the 19th centuries. It was endorsed give rise to nationalism in the late 18th and in the 19th centuries. It was endorsed by the mystification of religious 'covenantalism'. In such a 'civil-like religion, the biological kinship is equated with ecclesial membership that is ritualised by the baptism of children on the initiative of biological parents. The emphasis on biological kin as integral to divine redemption during the period of formative Christianity appeared again hundreds of years later in institutional Christianity. An illustration of the importance of 'bio-politics' can be seen in the custom of parents bringing their children to be baptised as members of the church.

5.According to the translation in the International Standard Version: 'So God created mankind in his own image; in his own image God created them; he created them male and female. God blessed the humans by saying to them, "Be fruitful, multiply, fill the earth, and subdue it! Be masters over the fish in the ocean, the birds that fly, and every living thing that crawls on the earth!' (Gn 1:27-28) (The Holy Bible 2011).

6.With regard to Plato (see Schofield [ed.] \& Griffith [transl.], 2016, Plato: Laws), Price (1989:230) puts it as follows: 'This becomes explicit in Laws [Nómol]. An early passage there contrasts a kind of heterosexuality with homosexuality: "When male passage there contrasts a kind of heterosexuality with homosexuality: "When male and female came together to share in procreation, the pleasure they experience
seems to have been granted according to nature; but same-sex relations seem to be unnatural...

7.According to Saxonhouse (1982:206), 'Aristotle does assert that by nature (phusei) the male is more capable of command than the female, though in abnormal circumstances (para phusin) the opposite may be true. On the other hand, the relationship between father and children is of necessity, and by definition, one of rule by the older and more complete (teleion) over the younger and incomplete. Not even in abnormal circumstances could the opposite hold'. Kullmann (1991) points out that what is 'according to nature', that is 'normal circumstances', is for points out that what is 'acu 'Aristotle considers the procreation of an anim, is for Aristotle divinely ordained: 'Aristotle considers the procreation of an animal as a teleogical, goal-directed process....be found in nature...[O]n occasion [Aristotle] expresses the view that nature is the agent as if it were a divine creator. Thus, one of his assertions is, "Nature does nothing in vain" (Aristotle. De caelo 271a.33; 291b.13-14; De anima 432b.21; 434a.41, De partibus animalium 661b.24; 691b.4-5; 694a.15; 695b.19-20; De generatione animalium 739b.19; 741b.4 744a.37-38 - see Barnes (2014) 
same-gender sex in the same vein as the 'sin of onanism'. This pejorative disapproval is inferred from a biblical story. God killed Onan, son of Judah (see Gn 38:9-10), who 'spilled his semen' in his disobedience to the cultural commitment to maintain the levirate marriage. The 'sin of onanism' pertains disobedience to the obligation of procreation. ${ }^{8}$ This resulted in the stigmatisation of masturbation and samegender sex. ${ }^{9}$

Johann Beukes ([2021; cf. Beukes 2020], finding his point of departure in Michel Foucault's posthumously published Histoire de la sexualité ' 4 ' (Les aveux de la chair) (also see Raffnsøe 2018), makes an important contribution to the generation of new knowledge regarding Augustine's interpretation of Romans 1:26. Beukes argues that Augustine was in particular the initiator of the insight that feminine homoeroticism was 'underemphasised' in the period preAugustine, and that the same pertained during the time span between the patristic period and the beginning of the circulation of the so-called Libri Poenitentiales - handbooks on penance - from the 6th century onwards till medieval times (See McNeil \& Gamer 1990). Foucault demonstrates that since that time same-gender sex was seen as a punishable sin. However, Augustine's interpretation of the Greek expression para phusin as 'against nature' represents a trend also found in the thinking of non-Christian writers such as Plutarch (c. 48 CE - c. 119 CE) (Walcot 1998) and Themistios (317-387 CE) ${ }^{10}$.

The contribution of this author is to demonstrate a much more influential impact from another non-Christian thinker, namely Artemidorus of Daldis (cf. Dreyer 2008b:513). I herewith want to show how modern-day homophobia and aversion to same-gender sex do not have its ground primarily in Paul's use of para phusin, but that both Paul and Augustine, as well as other present-day homophobes in the Christian (including the Reformed) tradition, do have their roots in a non-Christian conviction without realising its intercultural and non-Christian origins.

\section{Artemidorus of Daldis}

It is important to consider that para phusin ( $\pi \alpha \rho \grave{\alpha} \varphi v ́ \sigma ı)$ is an expression that also appears in one of the oldest classifications of sex acts in the ancient civilisation, namely that of Artemidorus of Daldis (Asia Minor) in his work Oneirokritika (1.78-80), that was written in the 2nd century CE (see Harris-

\section{Wilkinson (1978:455) refers as follows to Augustine's view on onanism: 'St Augustine condemned married couples who practised infanticide, abortion or the use of "sterility poisons" (presumably contraceptives). He also condemned the Manichaean use of the so-called sterile period and unfruitful modes of intercourse in general, adding "That is what Onan, son of Judah did, and God killed him for it." Actually, the $\sin$ of Onan was his frustration of Judah's injunction that he should beget children by his brother's widow, not the method by which he did it. But the mistaken interpretation given to Genesis $38: 8-10$ by some Rabbis and St Augustine was perpetuated by St Jerome in the way he translated the passage in the Vulgate with the appalling result that what became known as "onanism" was branded for all Christendom as a sin, and one worthy of the severest condemnation'.}

9. However, see Donald Capps: '[T]he displacement of moral disapproval from masturbatory behavior to homosexual behavior leads to the stigmatization of those who engage in homosexual behavior, and an attitude of moral superiority and personal condescension inevitably follows' (Capps 2003:249).

10.An alternative spelling for Themistios is Themistius. For the content of Themistius's views on sexuality, see Penella 2000, The private orations of Themistius.
McCoy 2012). ${ }^{11}$ Artemidorus distinguishes between three

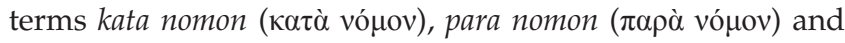

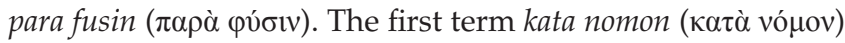

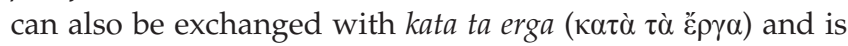
usually translated as 'according to convention'. Pederasty (the Athenian custom of older men who prefer sex with younger men $)^{12}$ falls into this category.

Other matters, such as (male) masturbation, 'passive' sex by a woman with another woman, sex with a (male) deity or sex with a corpse (in a 'passive' or 'active' role), are classified ${ }^{13}$ as para fusin (i.e. 'against nature').

In all probability, Paul's use of the expression para fusin in Romans 1:26 was influenced by the same culture as that of Artemidorus' (cf. Wengst 1987). Research by ancient cultural historians showed that the classification by Artemidorus goes as far back as the pre-Christian era. ${ }^{14}$

Although many years have passed between the life and times of Paul and Augustine, this father of the church is an important link in the history between Paul, Artemidorus and the church in both the Roman-Catholic (as well as the Eastern Orthodox) and the Protestant tradition. It is, however, interesting to observe that Augustine (De nuptiis et conupiscentia 20.35) interpreted the description of 'forbidden sex', referring to sex that does not have procreation as purpose - for example, anal or oral sex - as based on Romans 1:26-27. However, Augustine differs from his contemporaries who interpreted Romans 1:26-27 as a reference to samegender sex. It does not take away from the fact that Augustine condemned same-gender sex in other publications, such as Epistulae (211.13-14) and De opera monacharum (32.40), as did his contemporaries. However, he did not use Romans 1:18-32 as a reference. Augustine indeed describes the expression used in Ephesians 5:12, 'sin beyond words', in his work De bono coniugali $(10.11-11.12 ; 8.8)$ as 'contra naturam', in other words, 'against nature'. The reason is because 'contra naturam'

11'Since Foucault ([1978] 1990:3) drew attention to Artemidorus in The Care of the Self, the third volume of his The History of Sexuality, first published in French in
1984 (Foucault [1978] 1990), several scholars have stressed the significance of Artemidorus' substantial text for the study of ancient psychosexual ideologies' (Hall 2011:206; cf. also Davidson 2001:3-51)

12.For an accessible overview of the complex system of rules regarding Knabenliebe in classical Athens, see Waterfield (2002:xiii-xvi): 'apart from being an upper-class phenomenon and Athenian men's general preference for both heterosexual and same-sex anal intercourse for fear of unwanted pregnancies, the "love for boys" was deeply ritualised. While a postpubescent boy (around the age of 15) was "in bloom," as the Greeks called it, several older men, from their later twenties bloom, as the Greeks called it, several older men, from their later twenties onward, would pursue him. These older men were "the ones feeling passion, while the boy would most likely feel little or nothing beyond sexual arousal [...] The boy was expected to be merely passive, to let the successful suitor have his way [... This inequality is reflected in the relevant Greek terms: "lover" translates erastes, literally "a man feeling eros", while the boy is the eromenos, just the object of the lover's eros. What the boy got out of the affair - and that is why it was an upperclass phenomenon - was a form of patronage. In return for granting his sexua favours, he would expect the older man to act as an extra guardian in public life [...] Moreover, the older man was expected to cultivate the boy's mind - to be an intellectual companion. It was, in effect, a form of education [...] Such homoerotic relationships were widely tolerated but not universally approved (in Phaedrus, see 234b, 231e and 255a). It was felt that there was something demeaning about it, especially for the boy [...] (However,) [l] ust in any context was never approved of [...] we can be sure that Plato himself (and probably the historical Socrates) disapproved of giving in to sexual passion. The first evidence for this comes from Phaedrus itself, at 250e-251a and 253c-256e [..."' (Waterfield 2002:xiv-xv; quoted from: Beukes, 2021b, 'Methodius of Olympus', footnotes $32 \& 33$ ).

13.For the semantic difference, see, among others, Winkler (1990).

14.See Thonemann's (2020:139) reference to the citation from the Erotica, authored by Euenus of Paros (5th century BCE) in Artemidoros, Oneirocritica 1,15 - also found in Plutarch, Moralia 497A. 
according to him could refer to the same-gender (vaginal, anal or oral) sex (see Brooten 2003:187, n. 11).

According to Augustine (De bono coniugali 17.19), the purpose of marriage for all peoples (= in omnibus gentibus), in other words for Christians as well as non-Christians, is the same, that is, to conceive (proles) children as well as to faithfully uphold chastity (fides). According to him (De bono coniugali 32.24), marriage has specifically for each Christian a further purpose and that is to protect the 'sanctity of the sacrament'. For Augustine $(1999: 48,56)$, the implication of divorce and remarriage whilst the marriage partner is still alive is permanently inadmissible. Augustine was of the opinion that sex is for the sake of 'recreation' (in other words, emotional and biological satisfaction and pleasure [Latin concupiscentia]) - also in a marriage - equal to 'prostitution'. He viewed adultery a mortal sin (De bono coniugali $6.6 ; 8.8$ ). Compared to other immoralities on his list of sexualities that he described as para fusin, he counted sex for recreation as being the least, yet immoral. Amongst these, he lists incest (especially with your mother), adultery and prostitution (i.e. sex with a prostitute). According to him, the only acceptable moral sexual 'act' is firstly celibacy (according to Augustine 'the best') (De bono coniugali 7.6; 8.8; 9.9; 23.28) and secondly sex in the marriage with procreation in view. Should spouses not want to conceive children, they are, according to Augustine, obliged to refrain from sex, which means celibacy in the marriage.

Besides the acceptable sexual act in a marriage, there are, according to Augustine (De bono coniugali 11.12), other acts that are not 'deadly sins'. These acts are more 'morally' acceptable and refer to a man's vaginal coitus with his wife (not having procreation in mind, but pleasure; thus conupiscentia). This would be more acceptable to Augustine than vaginal coitus with a prostitute although still immoral.

As far as the sexual activity para fusin is concerned (in other words anal and perhaps oral sex), that of sex with a prostitute is objectionable (execrabiliter), but less so than if it happens with one's wife; as for the woman, it is more harmful (turpior) if she is the cause that her husband has sex para fusin with her, rather than with another woman. Here Augustine's androcentric orientation becomes very clear. In the marriage, the Christian woman should rather 'allow' her husband to commit adultery than to have sex with her if the aim is not procreation! $!^{15}$

Not only does Augustine's male domination and anti-women feelings become apparent here but also that the prevailing cultural codes of shame and honour are more prescriptive than the three-part purpose of the marriage, namely (1) to create progeny (proles), (2) to uphold fidelity (fides) and (3)

15.Augustine, in De ordine 11.4.12, without condoning prostitution as such, does not object to married men engaging prostitutes if sexual gratification is the objective, with the marioctive, with the knowledge and even encouragement of their wives ('Remove prostitution from society and lust will destroy everything' - in Latin: Aufer meretrices de rebus humanis, turbaveris omnia libidinibus). According to Johann Beukes (email correspondence), sex within marriage without the explicit intent to procreate was for Augustine a far bigger moral problem than any kind of sex outside of marriage, including same-gender sex. the sanctification of the sacramental bond (sacramentum). Because of these three reasons, the marital status, according to him, offers more honour to the woman than virginity does (De bono coniugali 3.3). At the core of androcentrism is that the marriage gains a 'moral goodness' when children (rather boys than girls) are born from the marriage (cf. Børresen [1968] 1981:94-123).

The earliest available evidence, as far as I am aware, that divorce for Christians was prohibited because the solemnisation of marriage was to be permanent (i.e. is a sacrament), is found with Augustine (401 CE) in his publication De bono coniugali (32.24). Although this 'sacrament' (= 'permanency') argument could have been in force earlier, before $401 \mathrm{CE}$, history shows us that Augustine's controversy was directed at, amongst others, Jovian (cf. also Bullough \& Bullough 1991). The latter was of the opinion that matrimony as much as virginity is equal to honour and reputation (i.e. just as undefiled). Augustine also expressed his opinion against the 'Peligianist', Julian of Eclanum, who reasoned in the same manner as Jovian did (cf. inter al. Wu 2007). Augustine, however, conveniently keeps silent about his own history of (Gnostic) Manicheism. Manicheism viewed marriage as 'evil' because of a Gnostic anti-matter ideology.

The theologian Thomas Aquinas is the next link in PaulArtemidorus-Augustine. In his Summa theologiae (II-II Q.154), Thomas Aquinas developed the idea of the sacrament for the Roman Catholic Church in the 13th century CE (cf. Dreyer 2008a:732; Schillebeeckx 1965).

Marriage was already in the 12th century CE declared a sacramentum. In the 4 th century CE, the Vulgate translated the Greek concept mysterion (mystery) as sacramentum in Ephesians 5:32. The Latin meaning is the 'pledge of fidelity' and stems from Roman military life. That, however, was not the meaning that the writers of Ephesians (also in 3:4 and 3:9), Colossians (1:26-27) and Timothy (3:16) or Paul in 1 Corinthians (4:1 and $\mathrm{Rm}$ (16:25), respectively, meant with the word mysterion (see inter al. McKim 2001:198). The use of the word sacramentum by the Vulgate was related to the language normally used by soldiers when they made a solemn vow (commitment) of allegiance at their installation into the military unit (see Thatcher 1999:40; cf. Dreyer 2008b:516).

This custom led to the debate until this day, about the 'right' or 'prohibition' by the Roman Catholic Church of divorce; it is about whether spouses by mutual consent and by right of the priestly sacramental blessing, as well as on the basis of the coitus in the marriage, are irrevocably bound to each other. Marriage as a sacrament in the Roman Catholic Church has the function and sign that indicate that God in and through Jesus Christ reconciles people with and through himself (as baptism and communion for Christians are signs of divine reconciliation). 
The reception history of the notion of sacramentum, interpreted as being soteriologically beneficial as elaborated by Thomas Aquinas (the result of the marriage theology of Augustine), should be interpreted in terms of the word pair remedium of sacramentum. The last-mentioned term, although meant to be positively interpreted as a medicinum against deadly sin, in other words, that spouses practice sex without the intention to conceive children (in other words without using 'contraception') (see Mackin 1982) implies, according to the Harvard theologian, Fiorenza (1991:316), pessimism about sex. Therefore, for example, we find with Gregorius Nyssenus (Ode virginitate) a view according to which even a 'happy marriage' is regarded as being 'full of misery'. John Chrysostom mentions in the same manner 'virginity' life and 'marriage' death (Fiorenza 1991:316).

\section{Unmasking prejudice}

In general, my point of view and argument against the prejudice about gay and intersex people has several facets. I shall show at least five such viewpoints in this article, without a lengthy discussion.

Firstly, it is important to note that the term 'homosexuality' itself does not appear in the Bible but is used by translators to refer to the sexual orientation of people of the same gender. The term 'homosexual' was taken over by the English from German in 1892 (cf. inter al. Adrian Thatcher 2015:5-7; Stuart 2015:18-19). It does not originate from the Latin homo (human being), but from the Greek adjective homoios (ónoios), or adverb (ónoí $\omega s)$, meaning 'alike' or 'the same'.

Secondly, we should take note that an influential organisation such as the American Psychology Association (APA) played an important role that constitutions the world over, considers discrimination against gay persons or intersex people as being inhuman (see, for example, the statement by the United Nations in 2017). ${ }^{16}$ It is a criminal offense to discriminate against gay people and to subject them against their will to 'psychological' practices that try to evoke an aversion against their sexual orientation. The APA is the largest, professional organisation of psychologists worldwide with almost 140000 members. The United Nations' Human Rights Report mentioned that in '2013, Australia adopted the Sex Discrimination Amendment (Sexual Orientation, Gender Identity and Intersex Status) Act' - 'the first law to include intersex status as a stand-alone prohibited ground of discrimination'. In 2015, 'Malta adopted the Gender Identity, Gender Expression and Sex Characteristics Act - the first law

16.Intersex people are born with sex characteristics (including genitals, gonads and chromosome patterns) that do not fit typical binary notions of male or female bodies. Intersex is an umbrella term used to describe a wide range of natural bodily variations. In some cases, intersex traits are visible at birth while in others, they are not apparent until puberty. Some chromosomal intersex variations may not be physically apparent at all. According to experts, between $0.05 \%$ and $1.7 \%$ of the population is born with intersex traits - the upper estimate is similar to the number of red-haired people. Being intersex relates to biological sex characteristics, and is of red-haired people. Being intersex relates to biological sex characteristics, and is distinct from a person's sexual orientation or gender identity. An intersex person may be straight, gay, lesbian, bisexual or asexual, and may identify as female, male both or neither. Because their bodies are seen as different, intersex children and adults are often stigmatized and subjected to multiple human rights violations, including violations of their rights to health and physical integrity, to be free from torture and ill-treatment, and to equality and non-discrimination' (see United Nations Human Rights 2017). to prohibit surgery and treatment on the sex characteristics of minors without informed consent'. In a recent published article, Jones and Van den Heever (2020) refer to the legal act accepted in Germany on January 2019 that adopts 'intersex identity into law', and that this implies that 'intersex people can register themselves as such on birth certificates, passports and other official documents' (Jones \& Van den Heever 2021).

Thirdly, it is unacceptable to equate same-gender sex to promiscuity. It is nothing else than 'hate speech' to describe the 'negative' (sic) (in Dutch: 'schaduwzijden') results of the present-day so-called 'sexual revolution' as a potential provocation of 'animal-like' behaviour (see De Bruijne 2019:356). Sexual immoralities, such as rape, human trafficking and gender-based violence, are mainly a heterosexual matter.

Fourthly, the recognition of the reality that there exist 'sexual minorities', amongst which are the 'homosexual persons', cannot be seen as a threat to heterosexual marriages. The 'crisis' that marriage as an institution experiences in today's spirit of the times has nothing to do with the expectation that gay people must be accepted with respect by society. ${ }^{17}$

Fifthly, the view that gospel about Jesus of Nazareth calls upon us to condemn gay or intersex persons is an exegetical and theological-ethical mistake. ${ }^{18}$

However, this study did not focus on the five above-mentioned points but only on the specific understanding of Romans 1:18-32. The magnifying glass is rather not as such on the exegesis of this part of the Bible and neither on the part of Paul's theology in general. Professor Jeremy Punt, New Testament scholar at the Stellenbosch University, has shown and discussed the most important interpretations of Romans 1:18-32 in the journal HTS Theological Studies. Punt's (2007) article provides a good overview of the existing exegesis. The focus of the article was specifically on the 'meaning' and the

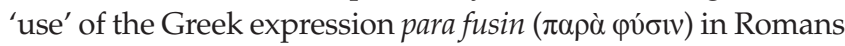
1:26, that is frequently translated 'unnatural' in English. The question addressed in the article is what could Paul have meant by this expression as written in Romans 1:26?

I therefore do not find it theologically justifiable that the prejudice against sexual minorities and the insistence that non-heterosexually orientated persons must live a celibate

17.According to O’Donovan (2017:157): 'Eine alles erschütterernde Umwälzung hat das Denken der westlichen Welt über Ehe und Sexuualität erfasst'. He sees the das Denken der westlichen Welt über Ehe und Sexuualität erfasst'. He sees the
heterosexual marriage as a 'gift of God' pertaining to a relationship defined as
'physische, moralische, spirituelle Wesen und in zwei biologische Geschlechtern' 'physische, moralische, spirituelle Wesen und in zwei biologische Geschlechtern'
(O'Donovan 2017:173). Over against such an essentialist binary point of view, (O'Donovan 2017:173). Over against such an essentialist binary point of view,
Dreyer (2008a), in her article "De-centre-ing" sexual difference in public and ecclesial discourses on marriage', argues: 'If marriage is in a crisis today it certainly is not the fault of people who have, for the longest time, had nothing to do with this up till recently exclusively heterosexual institution. The crisis in which marriage finds itself, if it is in fact a crisis, was caused by social changes within the heterosexual world itself' (Dreyer 2008a:725-726).

18.See, for example, Hester (2005:13-14) who points out the significance of both the gender and the sexuality of the eunuch character with reference to Matthew 19:12. The eunuch represents a 'morally dubious "third type of human" embodying the worst fears of masculine vulnerability and sexual transgression'. I am in concurrence with Hester who interprets this Jesus tradition as an 'explicit rejection of the heterosexist binary paradigm for understanding the role and importance of sex, sexuality and sexed identity in the "kingdom of heaven"' (Hester 2005:13; cf. Van Aarde 2020:213). 
life because same-gender sex is referred to in Romans 1:26 as being against nature (para fusin). This prejudice does not take into consideration that the implicit priority, that is at the basis of Romans 1:26, is no longer consistently applied as an ethical norm and recognised in the Protestant church. It is unreasonable to apply Romans 1:26 selectively only to gay persons. Protestants should be more serious about Luther's reform of the marriage (cf. inter al, Botha 2017:113-130; Buitendag 2007:445-460) as well as the imperative to desacramentalise the sex act. The Christian church should also not confuse cultural customs that form the context of the term against nature (para fusin), as these appear in Romans $1: 26$, with the gospel.

Inferences from this study represent an ellipse with two poles. The one point is the necessity that procreation ought neither be seen as the primordial centre of divine creation nor as the driving reason of sexual intercourse - inside or outside marriage - and subsequently that the idea of the 'sin of onanism' becomes obsolete. The other point is that sexual identity (see, inter al. Jones \& Van den Heever 2021; Raedel 2017a:119-156; Raedel 2017b:65 - in German 'Geschlechtsidentität und Geschlechtterrolle'; contra O'Donovan 2017:157-174) ought not to be defined in a binary way consisting of male and female but rather that the reality of intersexual multiple sexual identities should be embraced. ${ }^{19}$ This imperative should be realised in both religious and secular societal context (see inter al. Zorgdrager 2018).

The foundation of Christian ethics is the love of God that is given as a gift without prejudice to all people, asking Christians to similarly love all people without personal prejudice and bias. Rowan Williams (who was archbishop of Canterbury from 2002 till 2012), in his seminal reflection on identity and sexuality, entitled 'The body's grace', not only endorses John Boswell (1982:13) insight that the New Testament is notably nonbiological in its emphasis ${ }^{20}$ but also rejects the view that the Christian Bible legitimating only 19. Dreyer (2008a:735), referring to, among others, Beukes (2002), puts it as follows:
'According to Beukes (2002:297) patriarchal dominance in the public discourse on sexuality should bes (2002:297) patriarchal dominance in the public discourse on creates new from which polimorphic sexual identities emanate. Not much in Western society can be deemed purely male or purely female. Rather a highly androgenous quality has come to the fore. However, the sexuality of androgenous subjects and poligenious subjects such as queers, crossdressers and transvestites is as much poligenious subjects such as queers, crossdressers and transvestites is as much publicized as vanilla sexuality. Their private spaces too have already been infringed. An open circle of radical discretion would provide and guarantee them a private space without exception, without discrimination, without value-judgements, specifically because every sexual condition is kept silent and non-public" (trans Dreyer)". This insight can contribute greatly to pastoral engagement with gay people. From such a perspective all people who find themselves between maleness and femaleness will be respected in terms of the particular person him- or herself, whether gay, bisexual or heterosexual. In her article, "The "sanctity" of marriage an archaeology of a socio-religious construct: Mythological origins, forms and models', Dreyer (2008b:499-527) agreed with the point of view of Ward (1998:52-72) 'who goes beyond the traditional question of whether marriage is a sacrament of not. [Graham] focuses rather on marriage as a linguistic expression of intimacy in relationship. For him, heterosexual marriage is not the only possibility for expressing the intimate relationship between God and human beings. Same-sex relationships, for example, can provide a linguistic possibility of expressing this relationship, because such relationships can also embody values like intimacy, fidelity and unconditional love. The consequence of his argument is that the sexua difference between man and woman is not a prerequisite for God's salvific interaction with people' (Dreyer 2008b:500).

20.See my formulation of such a 'theo-anthropological truism' (Van Aarde 2020): 'In Jesus' distinctive bio-politics, the biological family was a matter of indifference [...] I argued that Jesus replaced 'politics of holiness' with 'politics of compassion'. This

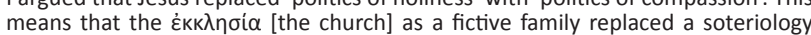
grounded in the biological family. God's 'adoption of people as children of God' is grounded in the biological family. God's adoption of people as children of God' is
based on the potential of [all] people to absorb the divine into their humanity (Van based on the potential
Aarde 2020:231,263) procreative heterosexuality (Williams 1989). In his 10th Michael Harding Memorial Address to the Lesbian and Gay Christian Movement in 1989, he said:

In fact, of course, in a church which accepts the legitimacy of contraception, the absolute condemnation of same-sex relations of intimacy must rely either on an abstract fundamentalist deployment of a number of very ambiguous texts, or on a problematic and non-scriptural theory about natural complementarity, applied narrowly and crudely to physical differentiation without regard to psychological structures. (Williams 1989)

How long will we still have to wait until such a claim for love will be unconditionally shown to gay persons and intersex people by the church and society at large?

\section{Acknowledgements Competing interests}

The author declares that he has no financial or personal relationships that may have inappropriately influenced him in writing this article.

\section{Author's contributions}

A.G.v.A. is the sole author of this research article.

\section{Ethical considerations}

This article followed all ethical standards for research without direct contact with human or animal subjects.

\section{Funding information}

This research received no specific grant from any funding agency in the public, commercial, or not-for-profit sectors.

\section{Data availability}

Data sharing is not applicable to this article as no new data were created or analysed in this study.

\section{Disclaimer}

The views and opinions expressed in this article are those of the author and do not necessarily reflect the official policy or position of any affiliated agency of the author.

\section{References}

Augustine [354-430 CE], 1999, The works of Saint Augustine, in Marriage and virginity, part. 1, vol. 9, transl. R. Kearney, New City Press, Hyde Park, NY.

Barnes, J., 2014, The complete works of Aristotle: The revised Oxford translation Princeton University Press, Princeton, NJ, (Bollinger Series LXXI-2), viewed 04 August 2021, from https://www.perlego.com/book/736554/the-completeworks-of-aristotle-the-revised-oxford-translation-onevolume-digital-edition-pdf.

Beukes, J., 2002, 'Ars erotica en die detrivialisering van die seksuele diskoers: 'n Aantekening by die seksualiteitsanalise van Michel Foucault' [Ars erotica and the detrivialization of the sexual discourse: An annotation to Michel Foucault's analysis of sexuality], HTS Teologiese Studies / Theological Studies 58(1), 283-298. analysis of sexuality], HTS Teologiese Studi
https://doi.org/10.4102/hts.v58i1.541

Beukes, J., 2020, "Histoire de la sexualité "4" (Les aveux de la chair): Aantekeninge vanuit die Nederlandse Foucault-navorsing' [Histoire de la sexualité ' 4 ' (Les aveux de la chair): Notes from the Dutch Foucault-scholarship], Verbum et Ecclesia 41(1), de la chair): Notes from the Dutch Foucault-sch
a2078. https://doi.org/10.4102/ve.v41i1.2078 
Beukes, J., 2021a, 'Augustinus en vroulike homoërotiek in die vroeë Middeleeue: 'n Foucaultiaanse ideëhistoriese interpretasie' [Augustine and female homoeroticism in the early Middle Ages: A Foucaultian idea-historical interpretation], HTS in the early Middle Ages: A Foucaultian idea-historical interpretation], HTS
Teologiese Studies/Theological Studies 77(4), a6880. https://doi.org/10.4102/hts. veologiese

Beukes, J., 2021b, 'Michel Foucault on Methodius of olympus (d.ca.311) in Les aveux de la chair: Patrick Vandermeersch's analysis contextualised', HTS Teologiese Studies/Theological Studies 77(4), a6912. https://doi.org/10.4102/hts.v77i4.6912

Børresen, K.E., [1968] 1981, Subordination and equivalence: The nature and role of women in Augustine and Thomas Aquinas, transl. C.H. Talbot, University Press of America, Washington, DC.

Boswell, J., 1982, Rediscovering gay history: Archetypes of gay love in Christian history, Gay Christian Movement, London.

Botha, A. \& Dreyer, Y., 2007, "n Feministiese narratief-pastorale perspektief op die huwelikbevestigingsformuliere van die Nederduitsch Hervormde Kerk' [A feminis narrative pastoral perspective on the marriage formularies of the Nederduitsch Hervormde Church], HTS Teologiese Studies / Theological Studies 63(3), 1275-1298. https://doi.org/10.4102/hts.v63i3.250

Botha, A., 2017, 'Verskuiwing van teologiese denke oor die huwelik vanaf Luther to vandag', HTS Teologiese Studies / Theological Studies 73(5), a4563. https://doi. org/10.4102/hts.v73i5.4563

Brooten, B.J., 2003, 'Nature, law, and custom in Augustine's On the good of marriage', in S. Matthews, C. Briggs-Kittredge \& M. Johnson-DeBaufre (eds.), Walk in the ways of wisdom: Essays in honor of Elisabeth Schlüssler Fiorenza, pp. 181-193, Trinity Press International (A Continuum Imprint), Harrisburg, PA.

Brownson, J.V., 2013, Bible, gender, sexuality: Reframing the church's debate on same sex relationships, Eerdmans, Grand Rapids, MI

Buitendag, J., 2007, 'Marriage in the theology of Martin Luther - Worldly yet sacred: An option between secularism and clericalism', HTS Teologiese Studies Theological Studies 63(2), 445-460. https://doi.org/10.4102/hts.v63i2.228

Bullough, V.L. \& Bullough, B., 1991, 'Should sex have a different meaning for humanists?', Humanism Today, vol. 6, pp. 139-156, viewed 14 August 2021, from https://americanhumanist.org/humanismtoday/vol6/./

Calvin, 1536, 'loannis Calvini Institutio Religionis Christianae', reprinted in G. Baum et al., (eds.), loannis Calvini opera quae supersunt omnia, vol. 1, pp. 1-251, translated as John Calvin: Institution of the Christian Religion, transl. L. Battles, 1975, John Knox Press, Atlanta, GA, viewed 02 August 2021, from https://archiveouverte.unige.ch/unige:650.

Capps, D., 2003, 'From masturbation to homosexuality: A case of displaced moral disapproval', Pastoral Psychology 51, 249-272. https://doi.org/10.1023/A 1022531614396

Countryman, L.W., 1988, Dirt, greed and sex: Sexual ethics in the New Testament and their implications for today, Fortress, Philadelphia, PA.

Cranfield, C.E.B., 1975, A critical and exegetical commentary on the Epistle to Roman (International Critical Commentary), 2 vols., T\&T Clark, Edinburgh.

Davidson, J., 2001, 'Dover, Foucault and Greek homosexuality: Penetration and the truth of sex', Past and Present 170(1), 3-51. https://doi.org/10.1093/past/170.1.3

Debel, H., 2009, “'Unnatural intercourse" in Rom. 1, 26-27: Homosexual or heterosexual?', in U. Schnelle (ed.), The letter to the Romans (Bibliotheca Ephemeridum Theologicarum Lovaniensium CCXXVI), pp. 631-640, Peeters, Leuven.

De Bruijne, A.LT, 2019 'Contouren van een christelijke seksuele ethiek', Theologia Reformata 62(4), 349-367. https://doi.org/10.21827/5dc3e87a60efe

De Wet, C.L., 2014, 'John Chrysostom on homoeroticism', Neotestamentica 48(1), $187-218$.

Dreyer, Y., 2008a, “"De-centre-ing” sexual difference in public and ecclesial discourses on marriage', HTS Teologiese Studies / Theological Studies 64(2), 725-738. https:// doi.org/10.4102/hts.v64i2.41

Dreyer, Y., 2008b, "The "sanctity" of marriage - An archaeology of a socio-religious construct: Mythological origins, forms and models', HTS Teologiese Studies Theological Studies 64(1), 499-527. https://doi.org/10.4102/hts.v64i1.10

Du Toit, A.B., 2007, 'Maar die grootste hiervan is die liefde', in C. Vos \& D. Human (eds.), Liefde is die grootste: Oor erotiek en seksualiteit, pp. 161-171, Protea Boekhuis, Pretoria.

Fiorenza, F.S., 1991, “Marriage”, in F.S. Fiorenza \& J.P. Galvin (eds.), Systematic theology: Roman Catholic perspectives, vol. 2l, pp. 305-346, Fortress, Minneapolis, MN.

Foucault, M., [1978] 1990, The history of sexuality, vol. 3: The care of the self, transl. R. Hurby, Vision Books, New York, NY.

Geyser, P.A., 2002, 'Bybelse getuienis oor homoseksualiteit - met ander oë gesien' [Biblical testimony on homosexuality - seen from another perspective], HTS Teologiese Studies / Theological Studies 58(4), 1655-1677. https://doi. org/10.4102/hts.v58i4.727

Hall, E., 2011, 'Playing ball with Zeus: Strategies in reading ancient slavery dreams', in R. Alston, E. Hall \& L. Proffitt (eds.), 2011, Reading ancient slavery (Bristoll Classical Press), pp. 224-228, Bloomsbury, London.

Harris-McCoy, D., 2012, Artemidorus' Oneirocritica: Text, translation, and commentary, Oxford University Press, New York, NY.

Hester, J.D., 2005, 'Eunuchs and the postgender Jesus: Matthew 19.12 and transgressive sexualities', Journal for the Study of the New Testament 28(1), 13-40. https://doi. org/10.1177/0142064X05057772

Hultgren, A.J., 1994, 'Being faithful to the Scriptures: Romans 1:26-27 as a case in point', Word \& World 14(3), 315-325.Jewett, R., 2007, Romans: A commentary (Hermeneia), Fortress, Minneapolis, MN.
Jones, C. \& Van den Heever, J., 2021, 'Building blocks of sexuality', HTS Teologiese Studies / Theological Studies 77(3), a6569. https://doi.org/10.4102/hts. v77i3.6569

Kullmann, W., 1991, 'Aristotle as a natural scientist', Acta Classica 34, 137-150, viewed 04 August 2021, from http://www.jstor.org/stable/24591937

Lenow, E., 2006, 'Exchanging the natural for the unnatural: Homosexuality's distortion of God's design', Southwestern Journal of Theology 49(1), 31-47.

Loader, W., 2014, 'Same-sex relationships: A 1st-century perspective', HTS Teologiese Studies / Theological Studies 70(1), 1-9, a2114. https://doi.org/10.4102/hts. v70i1.2114

Mackin, T., 1982, What is marriage?, Paulist Press, New York, NY.

Malick, D.E., 1993, 'The condemnation of homosexuality in Romans 1:26-27', Bibliotheca Sacra 150(599), 327-340.

McKim, D.K., 2001, The Westminster handbook to reformed theology, Westminster John Knox Press, Louisville, KY

McNeil, J.T. \& Gamer, H.M., 1990, Medieval handbooks of penance: A translation of the principal 'Libri Poenitentiales' and selections from related documents, the principal Libri Poenitentiales' and

O’Donovan, O., 2017, 'Schöpfung und Ehe: Kann sich Lehre entwickeln?', in C. Raede (ed.), Das Leben der Geschlechter: Zwischen Gottesgabe und menschlicher Gestaltung (Ethik im Theologischen Diskurs, Band 24), pp. 157-174, LIT Verlag Berlin.

Penella, R.J., 2000, The private orations of Themistius (Transformation of the Classical Heritage), University of California Press, Berkley.

Price, A.W., 1989, Love and friendship in Plato and Aristotle, Oxford University Press, New York, NY

Punt, J., 2007, 'Romans 1:18-32 amidst the gay-debate: Interpretative options', HTS Teologiese Studies / Theological Studies 63(3), 965-982. https://doi.org/10.4102/ hts.v63i3.238

Raedel, C., 2017a, 'Geschlechtsidentität und Geschlechtterrolle: Perspektiven theologischer Anthropologie, in C. Raedel (ed.), Das Leben der Geschlechter: Zwischen Gottesgabe und menschlicher Gestaltung (Ethik im Theologischen Diskurs, Band 24), pp. 119-156, LIT Verlag, Berlin.

Raedel, C., 2017b, Gender: Von Gender-mainstreaming zur Akzeptanz sexueller Vielfalt, Brunnen Verlag, Gießen.

Raffnsøe, S., 2018, 'Review essay: Michel Foucault's confessions of the flesh, the fourth volume of the history of sexuality', Foucault Studies 25, 393-421. https:// doi.org/10.22439/fs.v25i2.5593

Saxonhouse, A.W., 1982, 'Family, polity \& unity: Aristotle on Socrates' community of wives', Polity 15(2), 202-219. https://doi.org/10.2307/3234678

Schenker, J.G. \& Rabenou, V., 1993, 'Contraception: Traditional and religious attitudes', European Journal of Obstetrics \& Gynecology and Reproductive Biology 49(1-2), 15-18. https://doi.org/10.1016/0028-2243(93)90102-1

Schillebeeckx, E., 1965, Marriage: Human reality and saving mystery, Sheed and Ward, London.

Schofield, M. (ed.) \& Griffith, T. (transl.) 2016, Plato: Laws (Cambridge texts in the history of political thought), Cambridge University Press, Cambridge.

Schreiner, T.R., 1998, Romans (Baker Exegetical Commentary on the New Testament), Baker Academic, Grand Rapids, MI.

Scroggs, R., 1983, The New Testament and homosexuality, Fortress, Philadelphia, PA.

Smith, M.D., 1996, 'Ancient bisexuality and the interpretation of Romans 1:26-27', Journal of the American Academy of Religion 64(2), 223-256. https://doi. org/10.1093/jaarel/LXIV.2.223

Steyn, G.J., 2007, 'Riglyne vir die verstaan van homoseksualiteit binne die konteks van die Nuwe Testament', in C. Vos \& D. Human (eds.), Liefde is die grootste: Oor erotiek en seksualiteit, pp. 172-204, Protea Boekhuis, Pretoria.

Stuart, E., 2015, 'The theological study of sexuality', in A. Thatcher (ed.), 2015, The Oxford handbook of theology, sexuality, and gender, pp. 18-31, Oxford University Press, New York, NY

Thatcher, A., 1999, Marriage after modernity: Christian marriage in postmodern times, Sheffield Academic Press, Sheffield.

Thatcher, A., 2015, 'Introduction', in A. Thatcher (ed.), 2015, The Oxford handbook of theology, sexuality, and gender, pp. 3-17, Oxford University Press, New York, NY.

Thonemann, P., 2020, An ancient dream manual: Artemidorus' the interpretation of dreams, Oxford University Press, New York, NY.

United Nations Human Rights, 2017, Intersex, viewed 28 July 2021, from https://www. unfe.org/wp-content/uploads/2017/05/UNFE-Intersex.pdf.

Van Aarde, A.G., 2020, Jesus, Paul and Matthew, volume two: To and from Jerusalem Cambridge Scholars Publishing, Newcastle upon Tyne.

Van Oort, J., 2020, 'Sin and concupiscence', in T. Toom (ed.), The Cambridge companion to Augustine's 'confessions', pp. 93-106, Cambridge University Press, Cambridge.

Van Zyl, H.C., 2016, 'Romeine 1:26-27: Evaluering van eksegetiese en hermeneutiese argumente in die debat oor selfdegeslagverhoudings', In die Skriflig 50(2), a2072. https://doi.org/10.4102/ids.v50i2.2072

Vorster, J.N., 2006, 'The making of male same-sex in the Graeco-Roman world and its implications for the interpretation of biblical discourses', Scriptura 93, 432-454. https://doi.org/10.7833/93-0-1381

Walcot, P., 1998, 'Plutarch on sex', Greece \& Rome 45(2), 166-187. https://doi. org/10.1017/S0017383500033660

Ward, G., 1998, 'The erotics of redemption - After Karl Barth', Theology and Sexuality 1998(8), 52-72. https://doi.org/10.1177/135583589800400805 
Ward, R.B., 1997, 'Why unnatural? The tradition behind Romans 1:26-27', Harvard Theological Review 90(3), 263-284. https://doi.org/10.1017/S0017816000006349

Waterfield, R., 2002, 'Introduction', in R. Waterfield (intr. \& transl.), Plato. Phaedrus, pp. ix-xlix, Oxford University Press, Oxford.

Wengst, K., 1987, “Paulus und die Homosexualität", Zeitschrift fũr evangelische Ethik 31(2), 72-81. https://doi.org/10.14315/zee-1987-0106

Wilkinson, L.P., 1978, 'Classical approaches to population and family planning', Population and Development Review 4(3), 439-455. https://doi.org/10.2307/ 1972859

Williams, R., 1989, 'The body's grace', in 10th Michael Harding memorial address to the Lesbian and Gay Christian Movement in 1989, viewed 06 August 2021, from http://www.abc.net.au/religion/articles/2011/08/24/3301238.htm.
Winkler, J.J., 1990, The constraints of desire: The anthropology of sex and gender in ancient Greece, Routledge, New York, NY.

Witte, J., 1996, 'Moderate religious liberty in the theology of John Calvin', Calvin Theological Journal 31, 359-403.

Witte, J., 1997, From sacrament to contract: Marriage, religion, and law in the Western tradition (Oneirocricica), Westminster John Knox, Louisville, KY.

Wu, T., 2007, 'Did Augustine lose the philosophical battle in the debate with Julian of Eclanum on "concupiscentia carnis" and "voluntas?"', Augustiniana 57(1/2) 7-30, viewed 14 August 2021, from http://www.jstor.org/stable/44992815.

Zorgdrager, H., 2018, 'Het huwelijk opnieuw bekeken: Over christelijke verbeeldingskracht in een landschap van veranderende partnerrelaties', Kerk en Theologie 69, 213-225. 